\title{
A reestruturação departamental e o ensino de graduação na FMRP-USP
}

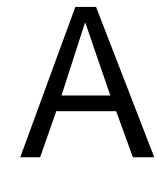

$\mathrm{s}$ recentes discussões sobre a reestruturação departamental, em andamento na Universidade de São Paulo (USP) e, em particular, na Faculdade de Medicina de Ribeirão Preto (FMRP), suscitaram naturais preocupações relativas aos possíveis efeitos das eventuais mudanças previstas sobre as diferentes atividades universitárias, entre as quais se inclui o ensino de graduação.

Para alguns dos críticos mais ferrenhos da citada reestruturação, esta determinação do Conselho Universitário, como instância deliberativa máxima da Universidade, poderia afetar negativamente o curso de graduação em Medicina. $\mathrm{Na}$ visão daqueles críticos, a possível extinção de alguns departamentos mais tradicionais da FMRP poderia, à guisa de exemplo, acarretar o desaparecimento do ensino sistematizado de conteúdos relevantes, próprios das áreas a serem extintas.

Nestes breves comentários, não se pretende entrar no mérito da decisão superior de promover ampla reestruturação dos departamentos existentes em todas as unidades da USP, nem considerar as particularidades de quaisquer das diferentes propostas formuladas para o enquadramento da FMRP às diretrizes estabelecidas. Tenciona-se, no entanto, explorar a idéia de que distorções no ensino de graduação, como as acima exemplificadas, já existem de longa data e estão, possivelmente, ligadas a outros fatores de maior peso, do que a referida reestruturação. Entre tais fatores, inclui-se a própria maneira de organização acadêmica em departamentos estanques, bem como a posição relativa, na escala de valores dominantes na cultura acadêmica contemporânea, do envolvimento docente no ensino de graduação.

O departamento, conquanto estrutura organizacional, substitutiva da cátedra, representou, à época da sua introdução, considerável avanço, principalmente no que se refere ao pleno e livre exercício das potencialidades acadêmicas individuais dos docentes, e ao aperfeiçoamento dos mecanismos de tomada de decisões, que passaram a ser mais democráticos e participativos. No entanto, a consolidação desta maneira de organização, ocorrendo concomitantemente com o crescimento explosivo do conhecimento e com a diluição das barreiras existentes entre as áreas mais tradicionais do saber, veio a caracterizar evidente distanciamento entre os interesses mais específicos dos departamentos e, em particular, dos diferentes grupos que os compõem, e as necessidades mais amplas do ensino de graduação.

A inadequação ocorreu efetivamente em muitos dos departamentos da FMRP, instituição que adotou tal forma de organização acadêmico-administrativa desde sua fundação. $\mathrm{Na}$ análise da conjuntura que precedeu à reestruturação curricular, levada a cabo nesta unidade da USP, no começo desta década, verificou-se um conjunto de distorções possivelmente associadas ao caráter departamental do ensino, até então existente. Entre as distorções, cumpre-se ressaltar 
o desenvolvimento, de modo estanque, de conteúdos absolutamente impertinentes, dado que desvinculados por completo dos objetivos mais gerais do curso de graduação. A inclusão dos conteúdos era garantida não pela sua importância inequívoca, mas tão somente pela existência de docentes com especialização no assunto. Do mesmo modo, conteúdos relevantes eram retirados do curso de graduação pela falta, no departamento, de experts na matéria e pelo desinteresse departamental em contratá-los.

Neste sentido, constata-se facilmente, ao exame dos autos dos processos de concessão de claros docentes aos diferentes departamentos da FMRP nos últimos anos, que tanto os pleitos departamentais como a análise do seu mérito, de modo a nortear as decisões institucionais, não priorizam, salvo exceções notáveis, as necessidades do ensino de graduação.

Tal estado de coisas, embora abrandado pela mencionada reorganização curricular, não parece ter sido afetado significativamente e não há razões para acreditar que deverá sofrer modificação considerável em qualquer uma das conformações que possam vir a ser adotadas na reestruturação departamental, em curso na FMRP. Isto porque sua origem está ligada, a meu ver, ao caráter corporativo do próprio modo de organização das faculdades em departamentos muito bem compartimentalizados, bem como ao fato de que há, inerente a este sistema, permanente competição dos departamentos por recursos materiais e humanos e por prestígio, segundo critérios que pouco privilegiam as atividades docentes no ensino de graduação.

A qualidade do ensino de graduação provido por um departamento é determinada por vários fatores. Dentre eles, vale ressaltar a exis- tência, no departamento, de pessoal docente com capacitação para o ensino de conhecimentos e habilidades específicas, bem como para atuar como role models adequados à formação geral do estudante. É improvável que os departamentos da nova estrutura a ser adotada pela FMRP passem a se preocupar adequadamente com este aspecto de grande importância para a instituição, como já não vêm se preocupando muitos dos atuais departamentos, o que ocorre porque as prioridades departamentais nem sempre coincidem com as institucionais, como o é o ensino de graduação.

O problema poderia ser sanado com a constituição de uma instância supradepartamental, com atribuições regimentais de pleitear a contratação de professores, a partir da análise das necessidades globais do ensino de graduação na instituição, bem como a de sugerir a alocação do novo docente no departamento mais apropriado. Estas atribuições poderiam ser assumidas pela Comissão de Graduação da FMRP que, em anos recentes, passou a funcionar como um colegiado supradepartamental de coordenação e administração do desenvolvimento de um currículo voltado a atingir objetivos educacionais mais abrangentes do que a soma dos conteúdos transmitidos pelos diferentes departamentos.

Além disso, uma estrutura curricular de ensino de graduação, com características supradepartamentais e interdisciplinares, como é a da FMRP, demanda o trabalho cooperativo do docente com seus pares de áreas similires do conhecimento, eventualmente provenientes de outros departamentos. Demanda, ainda, a disposição do docente em aprender e aplicar novas técnicas de ensino e, sobretudo, a sua disponibili- 
dade para colaborar com o ensino de outras matérias que não as estritamente relativas às áreas de sua atuação em investigação científica e em extensão de serviços. O desenvolvimento desta atitude no seio do corpo docente da instituição parece não depender da conformação departamental adotada, nem da própria maneira de organização acadêmica e administrativa, em departamentos. Parece, sim, depender da implantação de políticas institucionais, permanen- tes e eficazes, voltadas à mudança dos valores acadêmicos, de modo a garantir lugar de maior destaque ao ensino de graduação, como atividade universitária de importância primordial.

\section{Prof.Dr. LUIZERNESTO DE ALMEIDA TRONCON Presidente da Comissão de Graduação (1997 - abril /1999) \\ Professor Adjunto do Departamento de Clínica Médica da FMRP-USP}

